\title{
Effects of water-soluble fraction of petroleum on growth and prey consumption of juvenile Hoplias aff. malabaricus (Osteichthyes: Erythrinidae)
}

\author{
R. M. Santos ${ }^{a}$, L. Weber ${ }^{b}$, V. L. Souza ${ }^{b, c}$, A. R. Soares ${ }^{b}$ and A. C. Petry ${ }^{b *}$ \\ aPós-graduação em Ciências Ambientais e Conservação - PPG-CiAC, Universidade Federal do Rio de Janeiro - UFRJ, \\ Campus Macaé, Avenida São José do Barreto, 764, CEP 27965-045, Macaé, RJ, Brazil \\ bNúcleo em Ecologia e Desenvolvimento Socioambiental de Macaé - NUPEM, Universidade Federal do Rio de Janeiro - \\ UFRJ, Avenida São José do Barreto, 764, CEP 27965-045, Macaé, RJ, Brazil \\ ${ }^{\mathrm{c}}$ Centro de Pesquisas Gonçalo Moniz, Fundação Oswaldo Cruz - FIOCRUZ, Rua Waldemar Falcão, 121, \\ CEP 40296-710, Salvador, BA, Brazil \\ *e-mail: petryanacristina@gmail.com
}

Received: April 10, 2014 - Accepted: October 23, 2014 - Distributed: February 29, 2016

(With 2 figures)

\begin{abstract}
The influence of the water-soluble fraction of petroleum (WSF) on prey consumption and growth of juvenile trahira Hoplias aff. malabaricus was investigated. Juveniles were submitted to either WSF or Control treatment over 28 days, and jewel tetra Hyphessobrycon eques adults were offered daily as prey for each predator. Total prey consumption ranged from 16 to 86 individuals. Despite the initially lower prey consumption under WSF exposure, there were no significant differences in overall feeding rates between the two treatments. Water-soluble fraction of petroleum had a negative effect on the growth in length of $H$. aff. malabaricus juveniles. Although unaffected, prey consumption suggested a relative resistance in $H$. aff. malabaricus to WSF exposition and the lower growth of individuals exposed to WSF than the Control possibly reflects metabolic costs. The implications of the main findings for the individual and the food chain are discussed, including behavioral aspects and the role played by this predator in shallow aquatic systems.
\end{abstract}

Keywords: body size, ecotoxicology, growth performance, juvenile trahira, predation, survival.

\section{Efeitos da fração solúvel de petróleo no crescimento e consumo em juvenis de Hoplias aff. malabaricus (Osteichthyes: Erythrinidae)}

\begin{abstract}
Resumo
A influência da fração solúvel de petróleo (FSP) no consumo de presas e crescimento de juvenis da traíra Hoplias aff. malabaricus foi investigada. Os juvenis foram submetidos aos tratamentos FSP e Controle durante 28 dias, e adultos de matogrosso Hyphessobrycon eques foram oferecidos diariamente como presa para cada predador. O total de presas consumidas variou de 16 a 86 indivíduos. Apesar do menor consumo inicial de presas sob exposição de FSP, não houve diferenças significativas nas taxas de consumo entre os dois tratamentos. A FSP teve um efeito negativo no crescimento em tamanho de juvenis de $H$. aff. malabaricus. Embora a ausência de efeito no consumo de presas sugira uma relativa resistência de $H$. aff. malabaricus à exposição à FSP, o menor crescimento em tamanho dos indivíduos expostos ao poluente reflete possivelmente custos metabólicos. As implicações dos principais resultados nos níveis do organismo e da cadeia alimentar são discutidos, incluindo aspectos comportamentais e o papel desempenhado por este predador em ecossistemas aquáticos rasos.
\end{abstract}

Palavras-chave: tamanho do corpo, ecotoxicologia, performance de crescimento, juvenis de traíra, predação, sobrevivência.

\section{Introduction}

Crude oil and its products are the main source of energy in modern society and account for $41 \%$ of the global energy demand, recently estimated at 8,677 million tons (IEA, 2012). Crude oil, or petroleum, has an organic origin and is classified as light, medium or heavy, depending on the dominant type of hydrocarbon, i.e., aromatic compounds containing one benzene ring, polynuclear aromatic compounds containing two or more benzene rings, or aliphatic-rich (long- or short-chain) compounds, respectively (Marchand et al., 2002). Petroleum may also contain other compounds, such as sulfur, nitrogen, and oxygen, as well as trace metals, such as nickel and 
vanadium (Johnston, 1984; Marchand et al., 2002). Most environmental disasters worldwide are related to petroleum exploration and related activities, such as transport (Wang and Fingas, 2003). The degree of an oil spill's impact depends on the amount and type of oil involved (Marchand et al., 2002), as well as on which organisms are involved and how they are exposed to the petroleum (Silva et al., 2009; Smit et al., 2009). According to the literature, oil spills have mostly large-scale consequences, such as the loss of biodiversity and ecosystem services (Sánchez et al., 2006; Antonio et al., 2011).

In water, petroleum undergoes physical and chemical processes (e.g., evaporation, dissolution, emulsion, photolysis, biodegradation), which generate a water-soluble fraction (WSF) (Daling et al., 1990; Pérez-Cadahía et al., 2004). The WSF of petroleum and its derivative products contain a mixture of polycyclic aromatic hydrocarbons (PAH); monoaromatic hydrocarbons, often referred to as BTEX (benzene, toluene, ethylbenzene and xylenes); phenols; heterocyclic compounds containing nitrogen and sulfur; and heavy metals. In aquatic organisms, WSF of petroleum may impair physiological integrity, and its chemical compounds may be disseminated throughout the food chain (Pérez-Cadahía et al., 2004). Therefore, under petroleum contamination, ecological interactions between trophic levels may extend the effects on an individual (Omoregie and Ufodike, 2000; Akaishi et al., 2004) to higher levels of the biological organization, eventually affecting the structure and function of communities and ecosystems (Collier et al., 1996; Elliott et al., 2002; Peterson et al., 2003). Although ecotoxicological studies on aquatic organisms are increasing in number (Akaishi et al., 2004; Hansen et al., 2011; Weber et al., 2013), the evaluation of petroleum toxicity on top consumers is still a neglected topic.

Fish species are well represented in all levels of consumers in aquatic food chains; therefore, they are an essential component of nutrient cycling and energy flow in marine and continental waters (Vanni, 2002; Whitfield and Elliott, 2002). The limited capacity for dispersal of the sedentary fish species inhabiting hydrological disconnected environments makes them highly vulnerable to conditions imposed by environmental contamination. Therefore, understanding how and to what extent WSF affects consumers represents the first step in predicting the effects of contamination on aquatic food chains (Van der Oost et al., 2003).

The trahira Hoplias aff. malabaricus (Bloch) is distributed in most Central and South American watersheds (Oyakawa, 2003). By preferentially inhabiting vegetated areas that favor their ambush feeding strategy (Ferreira, 2007; Petry et al., 2010), H. aff. malabaricus may play an important role as a main predator in communities found in streams and lakes (Mazzeo et al., 2010; Corrêa et al., 2012). In these environments, $H$. aff. malabaricus are able to mediate prey species coexistence by piscivory (Petry et al., 2010). They might also do so in coastal brackish water bodies of southeastern Brazil, which are inhabited mostly by freshwater fish species, including trahiras (Di Dario et al., 2013).

The southeastern coast of Brazil is subjected to intensive petroleum-related activities involving drilling and transport over the Campos Basin, an area of approximately $100,000 \mathrm{~km}^{2}$ between the $21 \mathrm{st}$ and $23 \mathrm{rd}$ southern parallels, which currently accounts for more than $80 \%$ of the Brazilian petroleum production (ANP, 2011). Although coastal lagoons in this region are mostly maintained by small streams, sporadic saltwater intrusion may occur via sandbar breaching events or during extreme high tides events (Caliman et al., 2010). In addition, diffuse pollutant inputs may originate from road runoff, domestic usage and licensed discharges of oil derivatives used as energy sources in urban areas (Marchand et al., 2002). Specifically, this study aimed to assess the effect of chronic exposure of Hoplias aff. malabaricus juveniles to WSF of petroleum by evaluating prey consumption rates and the conversion of acquired food into somatic growth.

\section{Material and Methods}

\subsection{Sampling and acclimatization}

Juveniles of $H$. aff. malabaricus were obtained in September 2012 via diurnal seining in coastal lagoons situated in northern Rio de Janeiro State. The ten juveniles ranged in size between 8.5 and $12.5 \mathrm{~cm}$ total length (Table 1). Acclimatization lasted 15 days and consisted of the individual maintenance of fish under a $12 \mathrm{~h}$ photoperiod at $25^{\circ} \mathrm{C}$ in $12 \mathrm{~L}$ glass aquariums containing filtered and UV-sterilized freshwater. A PVC tube $50 \mathrm{~mm}$ in diameter was installed in the bottom of each aquarium to be used as refuge. Adults of jewel tetra Hyphessobrycon eques (Steindachner) with mean size of $2.98 \pm 0.24 \mathrm{~cm}$ were commercially acquired and supplied to $H$. aff. malabaricus for consumption. Five preys were added to each aquarium, corresponding to a ratio of $2 \%$ of the predator mass per day (Monteiro et al., 2013). Feeding ceased three days before the beginning of the experiment, and non-consumed preys were removed.

The number of preys consumed per fish was registered and replaced daily. Three times a day, the aquariums were checked, and the dead preys were removed and replaced. Every $72 \mathrm{~h}$, the feces were removed by suction and the water level was re-established. Environmental parameters (temperature and dissolved oxygen) were measured daily with a YSI-85 meter and adjusted daily with air conditioner and pumps to $25 \pm 2{ }^{\circ} \mathrm{C}$ and $6 \pm 1 \mathrm{mg} \mathrm{L}^{-1}$, respectively.

\subsection{Water-soluble fraction of petroleum}

The WSF was prepared with heavy crude oil $\left(17^{\circ} \mathrm{API}\right.$; Trevisan et al., 2009) obtained from the Jubarte oil field situated $77 \mathrm{~km}$ from the southern coast of Espírito Santo State, at the Campos Basin, Brazil, following the method proposed by Anderson et al. (1974), with some modifications. One part crude oil $(1.2 \mathrm{~kg})$ was mixed with four parts of filtered and sterilized tap water $(4.8 \mathrm{~L})$ $(1: 4 \mathrm{w} / \mathrm{v})$ and homogenized in the dark with a magnetic stirrer for $24 \mathrm{~h}$ at $500 \mathrm{rpm}$. Afterward, the mixture was 
Table 1. Initial and final total length $(\mathrm{cm})$ and weight $(\mathrm{g})$ of Hoplias aff. malabaricus juveniles after 28 days of exposure to two levels of treatment (Control and WSF) and the total number of preys consumed.

\begin{tabular}{|c|c|c|c|c|c|}
\hline \multirow{3}{*}{ Treatment } & \multicolumn{4}{|c|}{ Body size parameters } & \multirow{3}{*}{$\begin{array}{c}\text { Number of } \\
\text { consumed preys }\end{array}$} \\
\hline & \multicolumn{2}{|c|}{ Initial } & \multicolumn{2}{|c|}{ Final } & \\
\hline & $\begin{array}{c}\text { Length } \\
(\mathrm{cm})\end{array}$ & $\begin{array}{c}\text { Weight } \\
\text { (g) }\end{array}$ & $\begin{array}{c}\text { Length } \\
\text { (cm) }\end{array}$ & $\begin{array}{c}\text { Weight } \\
\text { (g) }\end{array}$ & \\
\hline Control & 10.5 & 11.5 & 13.2 & 26.4 & 59 \\
\hline Control & 12.5 & 17.9 & 14.7 & 35.2 & 86 \\
\hline Control & 8.9 & 7.8 & 11.5 & 17.0 & 42 \\
\hline Control & 10.4 & 11.9 & 11.8 & 20.4 & 43 \\
\hline Control & 8.5 & 6.7 & 10.4 & 13.5 & 29 \\
\hline Mean \pm S.D & $10.2 \pm 1.6$ & $11.2 \pm 4.4$ & $12.3 \pm 1.7$ & $22.5 \pm 8.5$ & $51.8 \pm 21.9$ \\
\hline WSF & 12.1 & 18.5 & 13.4 & 28.5 & 54 \\
\hline WSF & 10.5 & 12.2 & 11.5 & 28.9 & 71 \\
\hline WSF & 9.2 & 8.4 & 9.6 & 9.9 & 16 \\
\hline WSF & 12.0 & 17.5 & 13.0 & 24.3 & 41 \\
\hline WSF* & 8.5 & 6.9 & 8.5 & 6.8 & 3 \\
\hline Mean \pm S.D & $10.5 \pm 1.6$ & $12.7 \pm 5.2$ & $11.2 \pm 2.1$ & $19.7 \pm 10.6$ & $37.0 \pm 27.6$ \\
\hline
\end{tabular}

*Data of an individual which died at the 13th day of experiment, therefore was excluded from all further analyses.

transferred to a separation funnel and left for $2 \mathrm{~h}$, after which the water fraction was collected. Undiluted, this fraction was considered $100 \% \mathrm{WSF}$ and was prepared and stored at the experimental room temperature.

A sample of the $100 \% \mathrm{WSF}$ of petroleum was sent to the CQA laboratory (Centro de Qualidade Analítica, Campinas, Brazil) for total hydrocarbon and BTEX analysis, as well for the evaluation of its iron, barium, strontium and sulfates contents. This laboratory employed methods for evaluating solid wastes established by the Environmental Protection Agency (EPA), American Public Health Association (APHA), American Water Works Association (AWWA) and Water Environment Federation (WEF). According to the results of the analysis, the quantity of hydrocarbons was below the level of detection $\left(<0.2 \mu \mathrm{g} \mathrm{L}^{-1}\right)$. The evaluation of metal contents indicated that the WSF contained $0.09 \mathrm{mg} \mathrm{L}^{-1}$ of iron, $0.09 \mathrm{mg} \mathrm{L}^{-1}$ of barium, $0.08 \mathrm{mg} \mathrm{L}^{-1}$ of strontium and $16.60 \mathrm{mg} \mathrm{L}^{-1}$ of sulfates.

\subsection{Feeding experiment}

The purpose of this assay was to evaluate the effect of WSF on prey consumption and growth in length and weight in the juveniles of $H$. aff. malabaricus. Therefore, the total length $\left(L_{\mathrm{T}}\right)$ and weight $(W)$ of each juvenile were recorded at the beginning and at the end of the experiment. The acclimatization conditions were maintained during the 28 days of the experiment, and the juveniles were distributed into two treatment groups with five replicates each: 1) the control set, $0 \%$ WSF (herein named Control); and 2) the exposed group, 50\% WSF (herein named WSF). The consumption rates were obtained as the proportion of preys consumed per day and per week. The increments in length $\left(G_{\text {LENGTH }}=\ln L_{\text {T final }}-\ln L_{\text {T initial }}\right)$ and weight $\left(G_{\text {WEIGHT }}=\ln W_{\text {final }}-\ln W_{\text {initial }}\right)$ were considered the finite growth rates in length and weight, respectively.
Once a week, the water was exchanged for freshly prepared water containing the same proportions of WSF for each treatment. The initial length and weight of the juveniles did not differ significantly between the two treatment groups (Student $t$-test: $t_{\text {length }}=-0.30$; d.f. $=8$; $P=0.77$; Student $t$-test: $t_{\text {weight }}=-0.50$; d.f. $=8 ; P=0.63$ ). At he end of the experiment, all juveniles were anaesthetized for the final measurements by submersion in filtered and sterilized freshwater containing $6.7 \mathrm{ml} \mathrm{L}^{-1}$ of benzocaine stock solution ( $80 \mathrm{~g}$ dissolved in $1 \mathrm{~L}$ ethanol).

\subsection{Statistical analysis}

The consumption and finite growth rates were evaluated as the response variables in this experiment. Repeated measures analysis of variance (rm-ANOVA) was performed using the general linear modeling procedure of the statistical package STATISTICA (StatSoft, 2007) and was applied to verify the effect of the treatment and time of exposure on the juvenile consumption rates. The rm-ANOVA design considered the treatment as the main factor, whereas the weekly consumption rate was considered as the repeated measures. Student's $t$-test was used to evaluate any possible effect of the experimental treatment on the number of prey consumed and finite growth rates. Assumptions of normality, homoscedasticity and sphericity were met (sphericity required in the rm-ANOVA) and $P<0.05$ was adopted as the statistical significance level.

\section{Results}

No mortality was observed in the Control units, and only one juvenile died after 13 days of WSF treatment, which was excluded from all analyses. Prey consumption per juvenile showed variation along the 28 days of the experiment, showing in mean a slight increase with time (Figure 1). Although fish in the Control group consumed 
more prey overall than did those in the WSF units (Table 1), differences in the total number of consumed prey between the two treatments were non-significant (Student $t$-test: $t=0.42$; d.f. $=7 ; P=0.69$ ).

Juveniles in the Control consumed more preys during the first two weeks $\left(1.6 \pm 1.2\right.$ prey.day $\left.{ }^{-1}\right)$ than those submitted to petroleum $\left(1.2 \pm 1.1\right.$ prey.day $\left.{ }^{-1}\right)$. At the third week, the juveniles from the Control showed a decay in their prey consumption, reestablishing it at the fourth week, maintaining it again at higher levels than the WSF treated individuals (Figure 1b). According to the rm-ANOVA, there was a significant effect of time on the consumption rates of $H$. aff. malabaricus juveniles (Table 2). Again, no significant effect was observed for treatment neither for the interaction between treatment and time of exposure (Table 2).

The final length and weight of the individuals were higher than the initial values in both treatments (Table 1; Figures $2 \mathrm{a}$ and $2 \mathrm{~b}$ ). The mean increment in length in the Control $(2.16 \pm 0.53 \mathrm{~cm})$ was more than

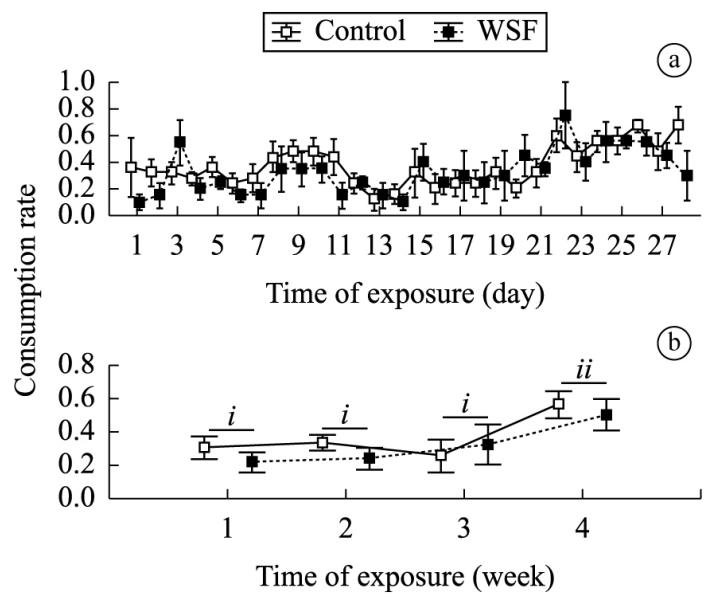

Figure 1. Prey consumption rates of Hoplias aff. malabaricus juveniles (Mean \pm S.E.) after 28 days in exposition to two levels of treatment (Control and WSF). (a) Number of preys consumed daily; (b) Number of preys consumed weekly. Letters above bars indicate the differences according to the rm-ANOVA.

Table 2. Effects of water-soluble fraction of petroleum on weekly consumption rates (number of preys consumed per week) in juveniles of trahira Hoplias aff. malabaricus exposed for four weeks (28 days) to two levels of treatment (Control and WSF), as determined by rm-ANOVA.

\begin{tabular}{lcccrr}
\hline \multicolumn{1}{c}{ Effect } & SS & d.f. & MS & F & \multicolumn{1}{c}{ P } \\
\hline Intercept & 4.29 & 1 & 4.29 & 41.75 & $<0.01$ \\
Treatment & 0.02 & 1 & 0.02 & 0.18 & 0.69 \\
Error & 0.72 & 7 & 0.10 & & \\
Repeated measure & & & & & \\
Time & 0.44 & 3 & 0.15 & 32.59 & $<0.01$ \\
Treatment $\times$ Time & 0.04 & 3 & 0.01 & 2.77 & 0.07 \\
Error & 0.09 & 21 & 0.01 & & \\
\hline
\end{tabular}

twice the increase observed in the treated individuals $(0.93 \pm 0.38 \mathrm{~cm})$ after 28 days of experiment (Table 1 ; Figure 2a). Significant differences in growth in length were found when the finite rates were evaluated (Figure 2c). Although the mean increment in weight was higher in the Control $(11.34 \pm 4.51 \mathrm{~g})$ than those exposed to WSF $(8.75 \pm 6.35 \mathrm{~g})$ (Figure $2 \mathrm{~b})$, differences in weight finite rates were not significant (Figure 2d).

\section{Discussion}

Several studies have assessed the effects of petroleum either as dispersed particles or as a soluble fraction (Collier et al., 1996; Heintz et al., 2000; Akaishi et al., 2004; Pérez-Cadahía et al., 2004; Hansen et al., 2011). Any intrusion of petroleum (e.g., from accidental spills on coastal waters) into enclosed water bodies will delay dispersion and increase the persistence of this pollutant. By inhabiting coastal lagoons, the trahira Hoplias aff. malabaricus may experience this source of contamination. A large number of studies demonstrating that WSF reduces water quality and the well-being of aquatic organisms are available. The negative effects of petroleum and its compounds on feeding and conversion of food in somatic growth have been demonstrated experimentally in a wide range of fish species, including species occupying marine, estuarine and freshwater environments (Heintz et al., 2000; Omoregie and Ufodike, 2000; Saborido-Rey et al., 2007). In addition, any effect on the individual-level might affect their development, progeny and ecological interactions with other individuals. The reduction in growth in length of $H$. aff. malabaricus juveniles exposed experimentally to petroleum observed in the present study adds to the limited amount of available evidence regarding the effect of petroleum on top predators at the whole organism level.

Although the juveniles exposed to WSF of petroleum in the present study grew less in length than the controls, they did not show differences in either consumption rates or weight. In the natural environment, the trahira $H$. aff. malabaricus exhibits ambush feeding on fish species, thereby expending low levels of energy on predation (Ferreira, 2007; Ramsdorf et al., 2009; Petry et al., 2010). The small artificial environment in which this experiment was carried out favored prey detection by the juveniles, which did not spend much energy on feeding activity. This finding related to the feeding behavior might explain in part the absence of a conspicuous effect from the treatment on consumption rates. Omoregie and Ufodike (2000) found that juveniles of the widespread introduced Nile tilapia Oreochromis niloticus (Linnaeus) fed less aggressively and ingested only $80 \%$ of the supplied food under the highest concentrations of WSF. The susceptibility to the experimental routine (weekly water and WSF renewal) was observed in the juveniles of the trahira $H$. aff. malabaricus mainly at the end of the first two weeks, by the decrease in predation rates in both treatments (Figure 1a). The increase in predation rate observed in both treatments on the last 

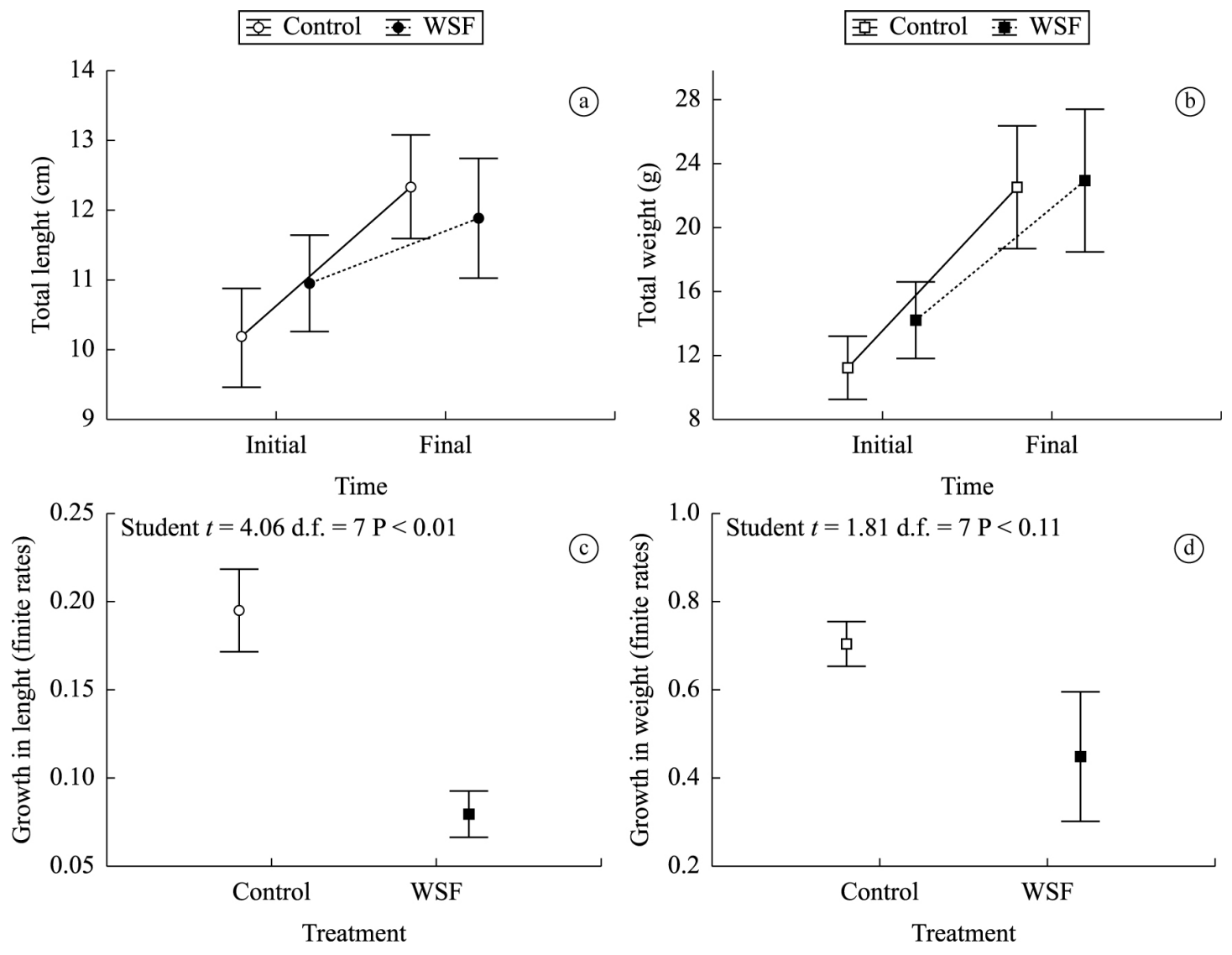

Figure 2. Growth of juveniles of Hoplias aff. malabaricus (Mean \pm S.E.) after 28 days exposed to two levels of treatment (Control and WSF). (a) Increase in total length (cm); (b) Total weight (g); (c) Growth in length (finite rates in length $=\ln L_{\text {Tfinal }}-\ln L_{\text {Tinitial }}$ ); (d) Growth in weight (finite rates in weight $=\ln W_{\text {final }}-\ln W_{\text {initial }}$ ).

week of the experiment was expected, due to fish growth (Loureiro and Hahn, 1996; Corrêa et al., 2012).

The absence of significant differences in weight increment between the treatments in this study may be expected because there is more investment of energy in growth in length rather than growth in weight (fat reserves) during the juvenile ontogenetic stage (Teixeira de Mello et al., 2006). Therefore, differences would be expected between the two treatment groups with respect to length growth rate in juveniles of $H$. aff. malabaricus. In fact, trahiras exposed to WSF in this study grew significantly less in length than those of the Control group. This outcome strongly suggests a negative effect of WSF on metabolism. Individuals in both treatments maintained similar consumption rates; therefore, we assume that those exposed to petroleum were unable to efficiently allocate the energy obtained from food to somatic growth in length. Nwabueze and Agbogidi (2010) reported a lack of growth in length for the African catfish Heterobranchus bidorsalis Geoffroy St. Hilaire submitted to concentration over 50\% WSF. We suppose that juveniles of $H$. aff. malabaricus exposed to petroleum used their energy for physiological compensation, rather than investing in somatic growth, which might be related to the activation of their detoxification mechanisms, as observed in juveniles of other fish species (Omoregie and Ufodike, 2000; Saborido-Rey et al., 2007; Esenowo and Ugwumba, 2010).

The detoxification metabolisms are associated with the commitment to homeostasis in individuals exposed to pollutants (Esenowo and Ugwumba, 2010). The degree of accumulation and retention of organic contaminants such as hydrocarbons is primarily dependent on the overall content and their distribution in tissues (Elliott et al., 2002). In mussels, it has been found that even low levels of PAHs ( $\left.5 \mathrm{ng} \mathrm{L}^{-1}\right)$ cause bioaccumulation and an increase in the levels of oxygenase enzymes involved in biotransformation (Pérez-Cadahía et al., 2004). After reviewing physiological and performance indicators of stress in fish, Schreck (1990) states that individuals may compensate for sublethal chronic conditions, recover in sublethal acute conditions or become exhausted and die.

Although this study detected a moderate effect of WSF in $H$. aff. malabaricus, the subtle changes in somatic growth may be important in the long term and may have consequences on the population level, such as reduced growth or population decline (Elliott et al., 2002). According to Heintz et al. (2000), recruitment and 
population dynamics may be affected by sublethal effects, such as reduction in growth.

The sensitivity of fish to petroleum was evaluated early on in Alaskan freshwater and anadromous species, and it was experimentally demonstrated that the median tolerance limit at $96 \mathrm{~h}$ (i.e., the concentration at which half of the animals survived the given period of exposure) may vary from one species to the other (Moles et al., 1979). These authors also observed that salmonids (the most sensitive group) maintained in saltwater were more sensitive to petroleum than those tested in freshwater, demonstrating that salinity also has an important effect. Several studies (Rantin et al., 1993; Luz and Portella, 2005) have reported that erythrinids, especially $H$. aff. malabaricus, have a high degree of resistance to environmental conditions involving hypoxia, long-term feeding deprivation and temperature extremes (Rantin et al., 1992; Rios et al., 2002; Rios et al., 2004; Petry et al., 2007), which negatively affect most of the sympatric fish species (Soares et al., 2006). The resistance characteristics of the trahira are most likely related to its sedentary behavior and low metabolism in contrast to the highly migrant and more active salmonids. The differences in energy expenditure between these aquatic top predators may explain, at least in part, their differences in susceptibility to petroleum.

It is thus concluded that 28 days of exposure to $50 \%$ WSF was non-lethal to juvenile $H$. aff. malabaricus, neither affecting prey consumption nor the growth rate in weight. Nevertheless, it affected negatively the growth rate in length of the individuals. Considering the ecological importance of the trahira as predator and potential keystone, the negative effect of WSF of petroleum reported herein may in long term affect the stability of its communities.

\section{Acknowledgements}

This study is part of the Master's degree thesis of the first author at the postgraduate program in Environmental Sciences and Conservation of the Federal University of Rio de Janeiro. The authors are very grateful to FINEP/PETROBRAS $(3175 / 06)$ for the research financial support and to CAPES and CNPq for the Scholarship to R.M. dos Santos and Productivity Research grant to A.C. Petry and A.R. Soares, respectively. We also thank J.M.S. de Souza, S. Stoffel and undergraduate and graduate students for their fieldwork assistance. This study was conducted in accordance with Brazilian legislation and was authorized (\#Macae09/2012) by the Ethics Committee of Animal Experimentation of the Federal University of Rio de Janeiro.

\section{References}

AGÊNCIA NACIONAL DO PETRÓLEO, GÁS NATURAL E BIOCOMBUSTÍVEIS - ANP, 2011. Anuário estatístico brasileiro do petróleo, gás natural e biocombustíveis. Rio de Janeiro. 227 p.

AKAISHI, F.M., ASSIS, H.C., JAKOBI, S.C.G., EIRASSTOFELLA, D.R., ST-JEAN, S.D., COURTENAY, S.C., LIMA, E.F., WAGENER, A.L.R., SCOFIELD, A.L. and OLIVEIRA
RIBEIRO, C.A., 2004. Morphological and neurotoxicological findings in tropical freshwater fish (Astyanax sp.) after waterborne and acute exposure to water soluble fraction (WSF) of crude oil. Archives of Environmental Contamination and Toxicology, vol. 46, no. 2, pp. 244-253. PMid:15106677.

ANDERSON, J.W., NEFF, J.M., COX, B.A., TATEM, H.E. and HIGHTOWER, G.M., 1974. Characteristics of dispersions and water-soluble extracts of crude and refined oils and their toxicity to estuarine crustaceans and fish. Marine Biology, vol. 27, no. 1, pp. 75-88. http://dx.doi.org/10.1007/BF00394763.

ANTONIO, F.J., MENDES, R.S. and THOMAZ, S.M., 2011. Identifying and modeling patterns of tetrapod vertebrate mortality rates in the Gulf of Mexico oil spill. Aquatic Toxicology, vol. 105, no. 1-2, pp. 177-179. http://dx.doi.org/10.1016/j.aquatox.2011.05.022. PMid:21718661.

CALIMAN, A., CARNEIRO, L.S., SANTANGELO, J.M., GUARIENTO, R.D., PIRES, A.P.F., SUHETT, A.L., QUESADO, L.B., SCOFIELD, V., FONTE, E.S., LOPES, P., SANCHES, L., AZEVEDO, F., MARINHO, C., BOZELLI, R., ESTEVES, F. and FARJALLA, V., 2010. Temporal coherence among tropical coastal lagoons: a search for patterns and mechanisms. Brazilian Journal of Biology $=$ Revista Brasileira de Biologia, vol. 70, no. 3, suppl., pp. 803-814. http://dx.doi.org/10.1590/S151969842010000400011

COLLIER, T.K., KRONE, C.A., KRAHN, M.G., STAIN, J.E., CHAN, S.L. and VARANASI, U., 1996. Petroleum exposure and associated biochemical effects in subtidal fish after the Exxon Valdez oil spill. American Fisheries Society Symposium, vol. 18 , pp. 671-683

CORREAA, F., CLAUDINO, M.C., BASTOS, R.F., HUCKEMBECK, S. and GARCIA, A.M., 2012. Feeding ecology and prey preferences of a piscivorous fish in the Lagoa do Peixe National Park, a Biosphere Reserve in Southern Brazil. Environmental Biology of Fishes, vol. 93, no. 1, pp. 1-12. http://dx.doi.org/10.1007/ s10641-011-9881-4.

DALING, S., BRANDVIK, J., MACKAY, D. and JOHANSEN, Ø., 1990. Characterization of crude oils for environmental purposes. Oil and Chemical Pollution, vol. 7, no. 3, pp. 199-224. http:// dx.doi.org/10.1016/S0269-8579(05)80027-9.

DI DARIO, F., PETRY, A.C., PEREIRA, M.M.S., MINCARONE, M.M., AGOSTINHO, L.S., CAMARA, E.M., CARAMASCHI, É.P. and BRITTO, M.R., 2013. An update on the fish composition (Teleostei) of the coastal lagoons of the Restinga de Jurubatiba National Park and the Imboassica Lagoon, northern Rio de Janeiro State. Acta Limnologica Brasiliensia, vol. 25, no. 3, pp. 257-278. http://dx.doi.org/10.1590/S2179-975X2013000300006.

ELLIOTT, M., HEMINGWAY, K.L., MARSHALL, S. and DUHAMEL, S., 2002. Data quality analysis and interpretation. In: M. ELLIOTT and K.L. HEMINGWAY. Fishes in estuaries. Oxford: Blackwell Science, pp. 510-554.

ESENOWO, I.K. and UGWUMBA, O.A., 2010. Growth response of catfish (Clarias gariepinus) exposed to water soluble fraction of detergent and diesel oil. Environmental Research Journal, vol. 4, no. 4, pp. 298-301. http://dx.doi.org/10.3923/erj.2010.298.301.

FERREIRA, K., 2007. Biology and ecomorphology of stream fishes from the rio Mogi-Guaçu basin, Southeastern Brazil. Neotropical Ichthyology, vol. 5, no. 3, pp. 311-326. http://dx.doi. org/10.1590/S1679-62252007000300012.

HANSEN, B.H., ALTIN, D., RØRVIK, S.V., ØVERJORDET, I.B., OLSEN, A.J. and NORDTUG, T., 2011. Comparative 
study on acute effects of water accommodated fractions of an artificially weathered crude oil on Calanus finmarchicus and Calanus glacialis (Crustacea: Copepoda). The Science of the Total Environment, vol. 409, no. 4, pp. 704-709. http://dx.doi. org/10.1016/j.scitotenv.2010.10.035. PMid:21130489.

HEINTZ, R.A., RICE, S.D., WERTHEIMER, A.C., BRADSHAW, R.F., THROWER, F.P., JOYCE, J.E. and SHORT, J.W., 2000. Delayed effects on growth and marine survival of pink salmon Oncorhynchus gorbuscha after exposure to crude oil during embryonic development. Marine Ecology Progress Series, vol. 208, pp. 205-216. http://dx.doi.org/10.3354/meps208205.

INTERNATIONAL ENERGY AGENCY - IEA, 2012 [viewed 10 April 2014]. Key world energy statistics [online]. Paris: Soregraph. Available from: www.iea.org

JOHNSTON, R., 1984. Oil pollution and its management. In: O. KINNE. Marine ecology: a comprehensive, integrated treatise on life in the oceans and coastal waters. Chichester: John Wiley \& Sons, pp. 1433-1582. Ocean Management, vol. 5. Part 3 Pollution and protection of the seas-radioactive materials, heavy metals and oil.

LOUREIRO, V.E. and HAHN, N.S., 1996. Dieta e atividade alimentar da traíra, Hoplias malabaricus (Bloch, 1794) (Osteichthyes, Erythrinidae), nos primeiros anos de formação do reservatório de Segredo - PR. Acta Limnologica Brasiliensia, vol. 8, pp. 195-205.

LUZ, R.K. and PORTELLA, M.C., 2005. Tolerance to the air exposition test of Hoplias lacerdae larvae and juvenile during its initial development. Brazilian Archives of Biology and Technology, vol. 48, no. 4, pp. 567-573. http://dx.doi.org/10.1590/S151689132005000500009 .

MARCHAND, J., CODLING, I., DRAKE, P., ELLIOTT, M., PIHL, L. and REBELO, J., 2002. Environmental quality of estuaries. In: M. ELLIOTT and K.L. HEMINGWAY. Fishes in estuaries. Oxford: Blackwell Science, pp. 322-409.

MAZZEO, N., IGLESIAS, C., TEIXEIRA-DE MELLO, F., BORTHAGARAY, A., FOSALBA, C., BALLABIO, R., LARREA, D., VILCHES, J., GARCÍA, S., PACHECO, J.P. and JEPPESEN, E., 2010. Trophic cascade effects of Hoplias malabaricus (Characiformes, Erythrinidae) in subtropical lakes food webs: a mesocosm approach. Hydrobiologia, vol. 644, no. 1, pp. 325-335. http://dx.doi.org/10.1007/s10750-010-0197-8.

MOLES, A., RICE, S.D. and KORN, S., 1979. Sensitivity of Alaskan freshwater and anadromous fishes to Prudhoe Bay crude oil and benzene. Transactions of the American Fisheries Society, vol. 108, no. 4, pp. 408-414. http://dx.doi.org/10.1577/15488659(1979) $108<408$ :SOAFAA $>2.0 . C O ; 2$

MONTEIRO, D.A., THOMAZ, J.M., RANTIN, F.T. and KALININ, A.L., 2013. Cardiorespiratory responses to graded hypoxia in the neotropical fish matrinxã (Brycon amazonicus) and traíra (Hoplias malabaricus) after waterborne or trophic exposure to inorganic mercury. Aquatic Toxicology, vol. 140-141, pp. 346-355. http:// dx.doi.org/10.1016/j.aquatox.2013.06.011. PMid:23891784.

NWABUEZE, A.A. and AGBOGIDI, O.M., 2010. Impact of water soluble fractions of crude oil on growth performance of the catfish Heterobrancuhus bidorsalis. Journal of Agricultural and Biological Science, vol. 5, no. 1, pp. 43-46.

OMOREGIE, E. and UFODIKE, B.C., 2000. Effects of water soluble fractions of crude oil on growth of the Nile Tilapia, Oreochromis niloticus (L.). Bulletin of Environmental Contamination and Toxicology, vol. 64, no. 4, pp. 601-605. http://dx.doi.org/10.1007/ s001280000045. PMid:10754059.
OYAKAWA, O.T., 2003. Family Erythrinidae (Trahiras). In: R.E. REIS, S.O. KULLANDER and C.J. FERRARIS JUNIOR. Check list of the freshwater fishes of South and Central America. Porto Alegre: EDIPUCRS, pp. 238-240.

PÉREZ-CADAHÍA, B., LAFFON, B., PÁSARO, E. and MÉNDEZ, J., 2004. Evaluation of PAH bioaccumulation and DNA damage in mussels (Mytilus galloprovincialis) exposed to spilled Prestige crude oil. Comparative Biochemistry and Physiology Part $C$ Toxicology \& Pharmacology, vol. 138, no. 4, pp. 453-460. http:// dx.doi.org/10.1016/j.cca.2004.08.001. PMid:15536053.

PETERSON, C.H., RICE, S.D., SHORT, J.W., ESLER, D., BODKIN, J.L., BALLACHEY, B.E. and IRONS, D.B., 2003. Long-term ecosystem response to the Exxon Valdez oil spill. Science, vol. 302, no. 5653, pp. 2082-2086. http://dx.doi. org/10.1126/science.1084282. PMid:14684812.

PETRY, A.C., AGOSTINHO, A.A., PIANA, P.A. and GOMES, L.C., 2007. Effects of temperature on prey consumption and growth in mass of juvenile trahira Hoplias aff. malabaricus (Bloch, 1794). Journal of Fish Biology, vol. 70, no. 6, pp. 1855-1864. http://dx.doi.org/10.1111/j.1095-8649.2007.01461.x.

PETRY, A.C., GOMES, L.C., PIANA, P.A. and AGOSTINHO, A.A., 2010. The role of the predatory trahira (Pisces: Erythrinidae) in structuring fish assemblages in lakes of a Neotropical floodplain. Hydrobiologia, vol. 651, no. 1, pp. 115-126. http://dx.doi. org/10.1007/s10750-010-0281-0.

RAMSDORF, W.A., FERRARO, M.V.M., OLIVEIRA-RIBEIRO, C.A., COSTA, J.R.M. and CESTARI, M.M., 2009. Genotoxic evaluation of different doses of inorganic lead (PbII) in Hoplias malabaricus. Environmental Monitoring and Assessment, vol. 158, no. 1-4, pp. 77-85. http://dx.doi.org/10.1007/s10661-0080566-1. PMid:18843540.

RANTIN, F.T., GLASS, M.L., KALININ, A.L., VERZOLA, R.M.M. and FERNANDES, M.N., 1993. Cardio-respiratory responses in two ecologically distinct erythrinids (Hoplias malabaricus and Hoplias lacerdae) exposed to graded environmental hypoxia. Environmental Biology of Fishes, vol. 36, no. 1, pp. 93-97. http:// dx.doi.org/10.1007/BF00005983.

RANTIN, F.T., KALININ, A.L., GLASS, M.L. and FERNANDES, M.N., 1992. Respiratory responses to hypoxia in relation to mode of life of two erythrinid species (Hoplias malabaricus and Hoplias lacerdae). Journal of Fish Biology, vol. 41, no. 5, pp. 805-812. http://dx.doi.org/10.1111/j.1095-8649.1992.tb02708.x.

RIOS, F.S., KALININ, A.L. and RANTIN, F.T., 2002. The effects of long-term food deprivation on respiration and haematology of the neotropical fish Hoplias malabaricus. Journal of Fish Biology, vol. 61, no. 1, pp. 85-95. http://dx.doi.org/10.1111/j.1095-8649.2002. tb01738.x.

RIOS, F.S., KALININ, A.L., FERNANDES, M.N. and RANTIN, F.T., 2004. Changes in gut gross morphology of traíra, Hoplias malabaricus (Teleostei, Erythrinidae) during long-term starvation and after refeeding. Revista Brasileira de Biologia $=$ Brazilian Journal of Biology, vol. 64, no. 3B, pp. 683-689. http://dx.doi. org/10.1590/S1519-69842004000400017. PMid:15620008.

SABORIDO-REY, F., DOMÍNGUEZ-PETIT, R., TOMÁS, J., MORALES-NIN, B. and ALONSO-FERNANDEZ, A., 2007. Growth of juvenile turbot in response to food pellets contaminated by fuel oil from the tanker 'Prestige'. Marine Ecology Progress Series, vol. 345, pp. 271-279. http://dx.doi.org/10.3354/meps06961.

SÁNCHEZ, F., VELASCO, F., CARTES, J.E., OLASO, I., PRECIADO, I., FANELLI, E., SERRANO, A. and GUTIERREZ- 
ZABALA, J.L., 2006. Monitoring the Prestige oil spill impacts on some key species of the Northern Iberian shelf. Marine Pollution Bulletin, vol. 53, no. 5-7, pp. 332-349. http://dx.doi.org/10.1016/j. marpolbul.2005.10.018. PMid:16343555.

SCHRECK, C.B., 1990. Physiological, behavioral, and performance indicators of stress. In: S.M. ADAMS. Biological Indicators of Stress in Fish: 8th American Fisheries Society Symposium, 1990, Bethesda, Maryland. Bethesda: American Fisheries Society, pp. 29-37.

SILVA, C.A., OLIVEIRA RIBEIRO, C.A., KATSUMITI, A., ARAÚJO, M.L.P., ZANDONÁ, E.M., COSTA SILVA, G.P., MASCHIO, J., ROCHE, H. and SILVA DE ASSIS, H.C., 2009. Evaluation of waterborne exposure to oil spill 5 years after an accident in Southern Brazil. Ecotoxicology and Environmental Safety, vol. 72, no. 2, pp. 400-409. http://dx.doi.org/10.1016/j. ecoenv.2008.03.009. PMid:18479748.

SMIT, M.G.D., BECHMANN, R.K., HENDRIKS, A.J., SKADSHEIM, A., LARSEN, B.K., BAUSSANT, T., BAMBER, S. and SANNI, S., 2009. Relating biomarkers to whole-organism effects using species sensitivity distributions: a pilot study for marine species exposed to oil. Environmental Toxicology and Chemistry, vol. 28, no. 5, pp. 1104-1109. http://dx.doi.org/10.1897/08-464.1. PMid:19045938.

SOARES, M.G.M., MENEZES, N.A. and JUNK, W.J., 2006. Adaptations of fish species to oxygen depletion in a central Amazonian floodplain lake. Hydrobiologia, vol. 568, no. 1, pp. 353-367. http://dx.doi.org/10.1007/s10750-006-0207-z.

STATSOFT, 2007 [viewed 10 April 2014]. Statistica: data analysis software system. Version 8.0 [online]. Cary. Available from: www.statsoft.com

TEIXEIRA DE MELLO, F., IGLESIAS, C., BORTHAGARAY, A.I., MAZZEO, N., VILCHES, J., LARREA, D. and BALLABIO,
R., 2006. Ontogenetic allometric coefficient changes: implications of diet shift and morphometric traits in Hoplias malabaricus (Bloch) (Characiforme, Erythrinidae). Journal of Fish Biology, vol. 69 , no. 6, pp. 1770-1778. http://dx.doi.org/10.1111/j.10958649.2006.01245.x.

TREVISAN, O.V., FRANÇA, F.A., OKABE, C.A. and LISBOA, A.C., 2009. Elements of a heavy oil technology development program. Terrae, vol. 6, no. 1, pp. 21-29.

VAN DER OOST, R., BEYER, J. and VERMEULEN, N.P.E., 2003. Fish bioaccumulation and biomarkers in environmental risk assessment: a review. Environmental Toxicology and Pharmacology, vol. 13 , no. 2, pp. 57-149. http://dx.doi.org/10.1016/S13826689(02)00126-6. PMid:21782649.

VANNI, M.J., 2002. Nutrient cycling by animals in freshwater ecosystems. Annual Review of Ecology Evolution and Systematics, vol. 33, no. 1, pp. 341-370. http://dx.doi.org/10.1146/annurev. ecolsys.33.010802.150519.

WANG, Z. and FINGAS, M.F., 2003. Development of oil hydrocarbon fingerprinting and identification techniques. Marine Pollution Bulletin, vol. 47, no. 9-12, pp. 423-452. http://dx.doi. org/10.1016/S0025-326X(03)00215-7. PMid:12899888.

WEBER, L., CARVALHO, L., SÁ, N., SILVA, V., BERALDINI, N., SOUZA, V. and CONCEIÇÃO, M., 2013. Genotoxic effects of the water-soluble fraction of heavy oil in the brackish/freshwater amphipod Quadrivisio aff. lutzi (Gammaridea) as assessed using the comet assay. Ecotoxicology, vol. 22, no. 4, pp. 642-655. http://dx.doi.org/10.1007/s10646-013-1055-z. PMid:23479060.

WHITFIELD, A.K. and ELLIOTT, M., 2002. Fishes as indicators of environmental and ecological changes within estuaries: a review of progress and some suggestions for the future. Journal of Fish Biology, vol. 61, suppl. A, pp. 229-250. http://dx.doi. org/10.1111/j.1095-8649.2002.tb01773.x. 